\title{
Profitability with Sustainability - The Success of an Innovative Agripreneur
}

\author{
Parveen Kumar*, Kunzang Lamo, D. Namgyal and Sonam Angchuk \\ KVK-Leh, SKUAST-K, India \\ *Corresponding author
}

\begin{abstract}
A B S T R A C T
Keywords

Cold desert,

Remunerative, Agri

preneur and

Sustainability

Article Info

Accepted:

17 June 2020

Available Online:

10 July 2020

The present research paper is the story of an innovative women vegpreneur, Yangchan Dolma from the cold arid desert of union territory of Ladakh. She has beaten her age and successfully brought together sustainability, profitability and gender equality in her farm. She has proved false the notion that agriculture is a non remunerative enterprise and shown that sustainability can be achieved even with scarce resources and in adverse climatic conditions. By growing different vegetables in the growing season as well as off season and in the open as well as in protected structures; Mrs. Dolma by successfully integrating all the local resources from his farm has proved that agriculture is not a lost battle.. For every one rupee invested by her she is getting back more than four rupees.
\end{abstract}

\section{Introduction}

The Ladakh region of the country is often called cold desert, as the region combines the conditions of both arctic as well as desert climate (Shafiq et al., 2016). It stands at a height of $2900 \mathrm{~m}$ to $5900 \mathrm{~m}$ above mean sea level and is one of the highest and coldest (Kumar and Namgyal, 2019). Wide diurnal and seasonal fluctuation in temperature with $40^{\circ} \mathrm{C}$ in winter and $+35^{\circ} \mathrm{C}$ in summer are observed. Vegetable production is a major source of livelihood for peoples in this region. Over the years, the vegetable production scenario and consumption choices have undergone drastic changes, compared to what was available some decades back. Agrotechniques and vegetable production calendar in Ladakh differs from lowland parts of the country. Vegetable farms in this region are smaller with an average 0.2 acre (Stobdon $e t$ al., 2018)

Yangchan Dolma is a 60 years old woman from village Saboo in Block Leh of District Leh in the union territory of Ladakh. Her husband Rinchen Tundup retired as a class one officer from the state planning department.

The couple has two daughters and own about 2 hectares of land of which 0.5 ha are uncultivable. Of the remaining 1.5 ha; 0.5 ha is under vegetable cultivation and rest under cereal crops. Here is a brief description of vegetable production status at her farm. 


\section{Materials and Methods}

The primary data was collected from the individual farmer using a well developed open ended interview schedule in a face to face situation. Data was than analyzed and tabulated accordingly. The gross income, net income and benefit cost ratio were calculated based on the variable cost only.

\section{Results and Discussion}

Mrs. Dolma grows different vegetables which include Tomato, potato, cauliflower, cabbage, spinach, carrot, onion, coriander, Kale and knolhol. She produces her own seed for many vegetables she grow. From the seeds seedlings are raised in nursery usually in small beds. During harsh winter the seedlings are raised in a green houses. For raising seedlings she has four green houses. The seedlings are also sold in the local market. Such is her brand value that peoples from adjoining villages also come to get seedlings from her. Some of seed is procured by her from the agriculture department as well as some from private players like Pahuja, Takki and Sultan seeds from New Delhi.

A look at table reveals the cost of cultivation involved in raising vegetables. For land preparation including ploughing twice or thrice, planking and preparing beds for raising nursery and planting seedlings, the cost involved is rupees 7,000. Similarly the cost for daily operations at the farm for one to two or three hours per person the men days used during the entire year stand at rupees 10,000. Miscellaneous expenses for plant based insecticides like neem oil, bio control agents and others stand at 3,000. The marketing is done through cooperative societies. The society charges seventy paisa per kilogram of their produce for the vehicle they arrange to collect the produce. Besides, eight percent of the amount of the produce is charged from the producers for salary and other expenditure of the staff. The marketing charge collectively stands at rupees 28,800 . The total cost of cultivation thus worked out is 56,800 . The net income from this enterprise stood at 2, 43, 600 with a benefit cost ratio of 4.2.

\section{Key characteristics of her vegetable farm}

\section{Sustainable approach}

Ensuring sustainability is the key component of her farm while raising various crops. For this she makes input of one enterprise from output of other. Mrs. Dolma successfully converts output of one enterprise into input of other enterprise. The output from livestock like animal dung, urine and farm waste like crop residues, wheat straw, fallen leaves are successfully turned into compost by her. This compost she uses to raise vegetables and cereal crops like wheat and Barley. For this she has also set up a compost unit.

\section{Protected cultivation}

For year round production of vegetables in the cold arid region, protected cultivation has also emerged as a powerful tool that ensures remunerativeness to the farmers of cold arid region (Kumar and Namgyal, 2019). Protected cultivation is a technique wherein the microclimate in the surrounding area of the plant is controlled partially or fully or modified to protect the crop from weather especially very low or high temperatures, hail storms and heavy rains. Mrs. Dolma successfully does year round cultivation of different vegetables using protected structures like green houses, low tunnels and trenches.

\section{Organic production}

The vegetable produced in her farm are totally organic. No chemicals are used for their production. Instead of chemicals for 
increasing fertility of soil and increase yields and controlling disease and insect/pests organic methods including use of neem oil and bio control agents are used by her.

\section{Off season vegetable production}

The off season vegetables produced by them in the greenhouse fetch them a very good price. They are sold at double the price in the off season. Usually Chinese cabbage and leafy vegetables like Spinach and Kashmiri spinach (Kashmiri Palak) are produced in the green house.

\section{Water harvesting}

During cold season there is a shortage of water due to the freezing temperature. To overcome the problem of water scarcity in these months, she also has constructed a farm pond like structure in which they store water through a bore well.

Table.1 Total income from vegetable production

\begin{tabular}{|c|c|c|c|c|c|}
\hline $\begin{array}{c}\text { S. } \\
\text { No }\end{array}$ & Vegetable & $\begin{array}{c}\text { Area } \\
\text { (kanals) }\end{array}$ & $\begin{array}{c}\text { Production } \\
(\mathbf{q t l s} .)\end{array}$ & $\begin{array}{c}\text { Rate (per } \\
\mathbf{k g})\end{array}$ & $\begin{array}{c}\text { Gross } \\
\text { income }\end{array}$ \\
\hline $\mathbf{1}$ & Cabbage & 1.0 & 15 & 30 & 45,000 \\
\hline $\mathbf{2}$ & Cauliflower & 1.0 & 17 & 40 & 68,000 \\
\hline $\mathbf{3}$ & Knolhol & 0.25 & 1.2 & 35 & 42,000 \\
\hline $\mathbf{4}$ & Kale* & 0.25 & 1.2 & 30 & 3,600 \\
\hline $\mathbf{5}$ & Carrot & 1.0 & 2.7 & 30 & 8,100 \\
\hline $\mathbf{6}$ & Spinach & 0.5 & 0.55 & 40 & 2,200 \\
\hline $\mathbf{7}$ & Tomato & 0.5 & 3.5 & 40 & 14000 \\
\hline $\mathbf{8}$ & Onion & 1.0 & 5.0 & 40 & 20,000 \\
\hline $\mathbf{9}$ & Chinese Cabbage & 1.0 & 15 & 50 & 75,000 \\
\hline $\mathbf{1 0}$ & Beet root & 0.5 & 3.0 & 35 & 10,500 \\
\hline $\mathbf{1 1}$ & Potato & 0.5 & 4.0 & 30 & 12,000 \\
\hline $\mathbf{1 2}$ & Total & $\mathbf{7 . 5}$ & $\mathbf{6 8 . 1 5}$ & & $\mathbf{3 0 0 4 0 0}$ \\
\hline
\end{tabular}

*is the local name of a leafy vegetable

Table.2 Cost involved and net returns (in Rs.) from vegetable production

\begin{tabular}{|c|c|c|c|c|c|c|c|c|c|}
\hline \multirow{2}{*}{$\begin{array}{l}\text { Land } \\
\text { preparation } \\
\text { (ploughing/ } \\
\text { planking) }\end{array}$} & \multirow{2}{*}{$\begin{array}{l}\text { Labour } \\
\text { cost } \\
@ \text { 500 } \\
\text { per } \\
\text { man } \\
\text { day }\end{array}$} & \multirow{2}{*}{$\begin{array}{l}\text { Miscell } \\
\text { aneous }\end{array}$} & \multicolumn{2}{|c|}{ Marketing commission } & \multirow{2}{*}{$\begin{array}{l}\text { Input } \\
\text { (Seed) }\end{array}$} & \multirow{2}{*}{$\begin{array}{l}\text { Total } \\
\text { cost }\end{array}$} & \multirow{2}{*}{$\begin{array}{l}\text { Gross } \\
\text { income }\end{array}$} & \multirow{2}{*}{$\begin{array}{l}\text { Net } \\
\text { Income }\end{array}$} & \multirow{2}{*}{$\begin{array}{l}\text { b:c } \\
\text { ratio }\end{array}$} \\
\hline & & & $\begin{array}{l}8 \% \text { of } \\
\text { total } \\
\text { amount }\end{array}$ & $\begin{array}{l}70 \text { paisa per } \\
\mathrm{kg} \\
\text { produce }\end{array}$ & & & & & \\
\hline 7,000 & 10,000 & 5,000 & 24,030 & 4,770 & 6,000 & 56,800 & $3,00,400$ & $2,43,600$ & 4.2 \\
\hline
\end{tabular}


Fig.1 Cost of different components in total cost of cultivation

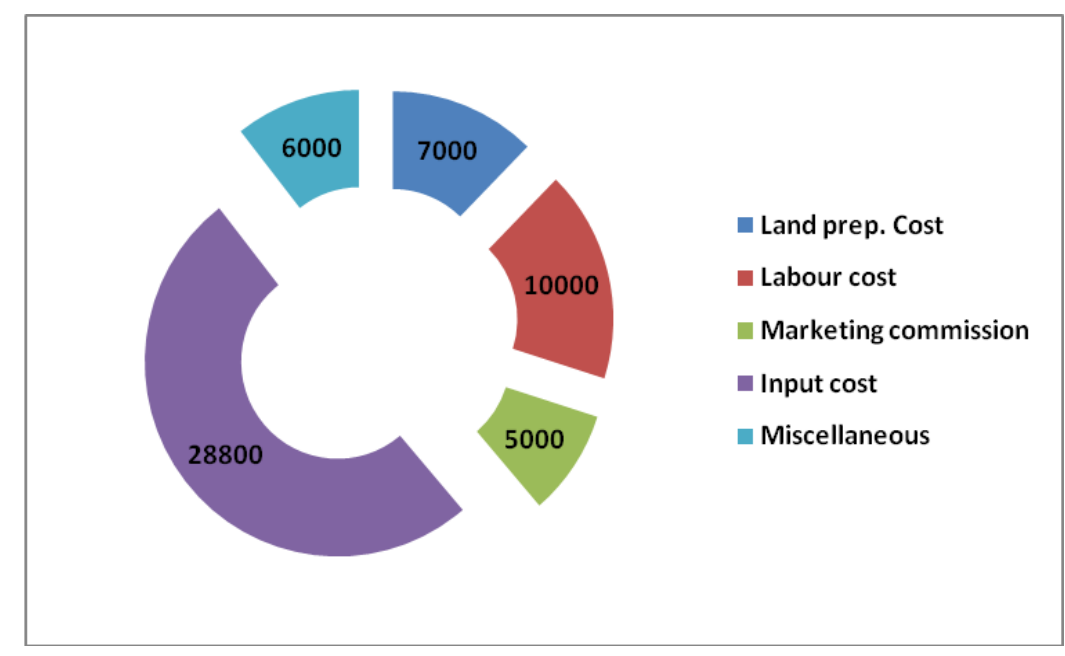

Fig.2 Cost of cultivation, Gross income and Net Income (in Rupees)

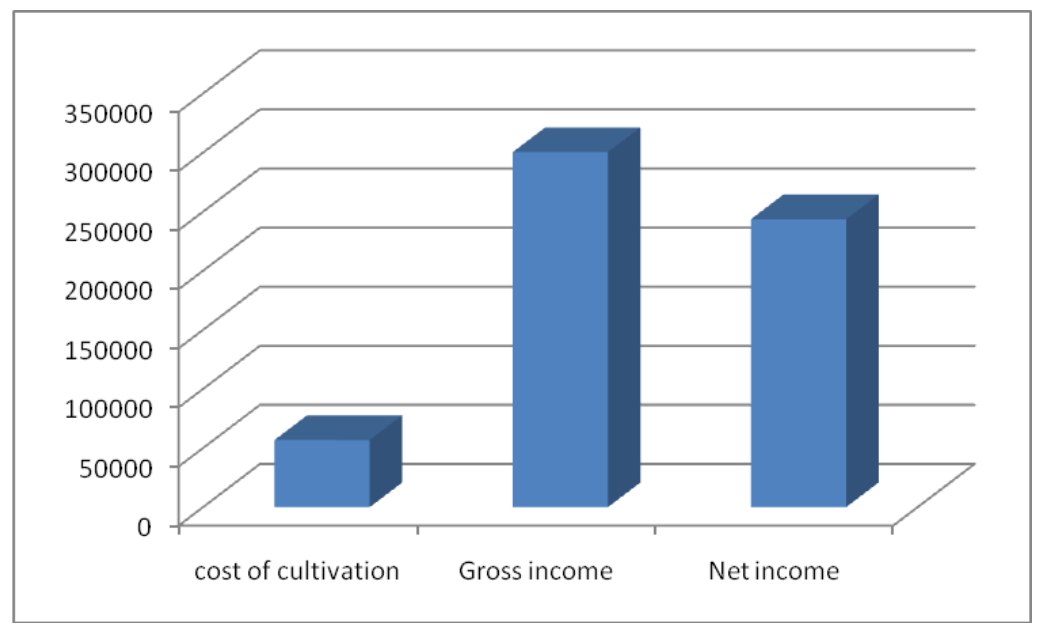

\section{Vegetable and flower seedlings}

Besides vegetable cultivation, they also produce seedlings of different vegetables and flowers like Dahlia, Petunia, Hibiscus, Marigold, Rose etc. She sells these seedlings to the locals of her village and adjoining villages and in the nearby market which also fetches her very good income.

\section{Post harvest processing and value addition}

For value addition and processing she has installed a solar drier where fruits like apricot and vegetables are dried for further processing and value addition. The value added products include dried apricots, apricot jam, tomato puree, dried vegetables, pickles etc. This value addition increases the market value of the produce and also enhances her income.

In conclusion the vegetable cultivation in this cold arid region started way back. Cunningham in 1854 mentioned of peas and turnip being grown in Ladakh. Moravian missionaries came to Leh in last quarter of the nineteenth century (Cunningham, A). They brought with them vegetable such as potatoes, 
spinach, cauliflower, radish, green beans, kholrabi, brussel's sprout and tomatoes. In the present era when sustainability, profitability and gender equality are the three main crucial issues confronting the agriculture sector in India, Mrs. Dolma has achieved all this under one roof. Today she is an inspiration for many of fellow farmers working in the area and the village to which she belongs is being recognized as a vegetable hub particularly for off season vegetable production in this cold arid region. In her endaveour towards sustainable production, KVK-Leh has provided her all the technical as well as advisory and diagnostic services in her endaveour for organic and off season production of different vegetables.

\section{References}

Cunningham, A. Ladakh: Physical, statistical, and historical with notices of the surrounding countries. Gulshan Publisher, Gowkadal, Srinagar, India, 1997.

Kumar, P and Namgyal, D. 2019. Agricultural Status in Cold Arid Ladakh. Greater Jammu. 2019, Oct. 1

Kumar, P and Namgyal, D. Protected cultivation: a blessing for cold arid ladakh. Early Times, 2019. Aug. 8.

Shafiq M. U, Bhat M. S, Rasool R, Ahmed P, Singh. $\mathrm{H}$ and Hassan H. Variability of Precipitation regime in Ladakh region of India from 1901-2000 Journal of Climatology and Weather Forecasting 2016. 4(2):1-4

Stobdan, T., Angmo, S., Angchuk, D. and Paljor, E. Dawa, T., Tsetan, T. and Chaurasia, O. P. Vegetable Production scenario in Trans Himalayan Leh Ladakh region. Defence Life Science Journal 2018. 3(1): Pp: 85-92

\section{How to cite this article:}

Parveen Kumar, Kunzang Lamo, D. Namgyal and Sonam Angchuk. 2020. Profitability with Sustainability - The Success of an Innovative Agripreneur. Int.J.Curr.Microbiol.App.Sci. 9(07): 2109-2113. doi: https://doi.org/10.20546/ijcmas.2020.907.245 